\title{
International authority and the emergency problematique: IO empowerment through crises
}

\author{
Christian Kreuder-Sonnen ${ }^{*}$ \\ WZB Berlin Social Science Center, Reichpietschufer 50, 10785 Berlin, Germany \\ ${ }^{*}$ Corresponding author. Email: christian.kreuder-sonnen@wzb.eu
}

(Received 2 September 2018; revised 17 January 2019; accepted 11 February 2019; first published online 13 March 2019)

\begin{abstract}
This paper applies the concept of emergency powers to the crisis politics of international organizations (IOs). In the recent past, IOs like the UN Security Council, the WHO, and the EU have reacted to large-scale crises by resorting to assertive governance modes bending the limits of their competence and infringing on the rights of the rule-addressees. In contrast to rational and sociological institutionalist notions of mission creep, this paper submits that this practice constitutes 'authority leaps' which follow a distinct logic of exceptionalism: the expansion of executive discretion in both the horizontal (lowering of checks and balances) and the vertical (reduction of legal protection of subjects) dimension, justified by reference to political necessity. This 'IO exceptionalism', as argued here, represents a class of events which is observable across fundamentally different international institutions and issue areas. It is important not least because emergency politics tend to leave longer-term imprints on a polity's authority structures. This article shows that the emergency powers of IOs have a tendency to normalize and become permanent features of the institution. Thus IO exceptionalism and its ratcheting up represent a mechanism of abrupt but sustainable authority expansion at the level of IOs.
\end{abstract}

Keywords: international organizations; crisis politics; authority; state of emergency; constitutionalism; mission creep; ratchet effect

Over the last two decades, international organizations (IOs) have played politically powerful and legally questionable roles in a diverse set of crises in world politics. In its reaction to the 9/11 terrorist attacks, for example, the United Nations Security Council (UNSC) vastly extended its jurisdiction by empowering itself to act as a global legislator and suspending due process rights of individuals. During the $2002 / 3$ SARS crisis, without prior legal or political authorization to do so, the World Health Organization (WHO) issued travel warnings for affected regions and encroached upon the sovereignty rights of some of its members. Since the outbreak of the euro crisis in 2010, the extra-legal empowerment of the European Central 
Bank (ECB) to act as a lender of last resort to sovereigns in the Eurozone and to impose austerity measures on recipient states (as part of the so-called Troika) is only the most visible of several crisis-induced shifts in the European Union's (EU) authority structures.

The paper contends that International Relations (IR) scholarship is conceptually ill-equipped to apprehend these phenomena. Abrupt expansions of IO authority are familiar to institutionalist scholarship, but only to the extent that they follow from acts of formal contractual delegation in moments of institutional creation or reform (e.g. Koremenos, Lipson, and Snidal 2001; Johnson 2014). Yet none of the mentioned authority increases came about in a formal process of delegation. The IOs widened the scope of their competence in an informal and - from a legal perspective - irregular way. Regarding informal/irregular IO task expansions, however, both rationalists and constructivists limit their analyses to instances of mission creep whereby bureaucratic IO organs slowly and incrementally deviate from their delegation contract with member states (Barnett and Finnemore 2004; Hawkins et al. 2006b; Lawrence 2008; Weaver 2008). They do not capture abrupt and assertive IO interventions in times of crises. On the one hand, the institutional changes effectuated by the UNSC, the WHO, and the ECB were abrupt, comparatively drastic, and salient - not slow, incremental, and barely noticed. On the other hand, they were also not primarily about IO bureaucracies conflicting with the directions of their collective member state principal. Rather, both bureaucratic and member state IO organs exercised (pooled or delegated) political authority (Zürn, Binder, and Ecker-Ehrhardt 2012; Hooghe and Marks 2015) in a manner bending the limits of their legal constitution based on more diffuse and variegated interest constellations among state and institutional actors. This is not a difference in degree, but a difference in kind.

To account for such institutional developments, I advocate a shift in analytical perspective. With the rise of international authority, ${ }^{1}$ IOs' political order dimension comes to the fore: As elements of hierarchy enter the institutional structure of international politics, the relationship between the holders (be they a subset of states or supranational institutions) and the addressees of authority (be they a subset of states, non-state entities, or individuals) is of central concern. In particular, the analysis of authority relationships raises the specter of 'constitutional' questions characterizing the political order in which they exist: How is authority constituted, constrained, and exercised? To what extent do the addressees of authority enjoy liberal and republican rights? Hence, I propose to adopt a constitutional perspective on IOs which shifts attention from member state-IO interactions to international authority and the constitutional configurations through which it is exercised. Just as we compare regime types across states, so we can compare the constitutional structures of IOs (Kreuder-Sonnen and Zangl 2015; 2016).

Adopting the constitutional perspective on IO authority, the above examples of international crisis politics appear in a different light. As argued in this paper, with

\footnotetext{
${ }^{1}$ In particular after the Cold War, many IOs have unevenly but consistently gained in political authority, understood as the ability to take collectively binding decisions beyond the zone of agreement every state individually and continuously consents to. Importantly, this ability pertains to both member state bodies with pooled authority and bureaucratic IO bodies with delegated authority, relaxing the intergovernmental-supranational opposition (see Hurd 2007; Lake 2010; Zürn, Binder, and Ecker-Ehrhardt 2012; Hooghe et al. 2017; Zürn 2018).
} 
the vocabulary of constitutional theory, they can be understood as cases of IOs assuming 'emergency powers': Not dissimilar to government practices in domestic states of exception, the IOs deploy emergency measures expanding their executive discretion and curtailing the rights of the authority-addressees, justified by reference to exceptional circumstances (see also White 2015b; Heath 2016; Scheuerman 2017; 2018). Understood as a distinct form of emergency politics beyond the state, this is what I call 'IO exceptionalism.' It is not about mission creep but about 'authority leaps' facilitated by the rationale of emergency: Based on the assumption that the strict observance of ordinary legality could be obstructive to the goal of providing existential public goods in extraordinary situations, the state of emergency is to facilitate an assertive mode of rule by suspending constraints on the exercise of authority - be they horizontal (i.e. checks and balances) or vertical (i.e. individual rights) (generally Gross and Ní Aoláin 2006; Fatovic 2009; Sorell 2013). Under the impression of threat and crisis, authority-addressees are generally more willing to accept such discretionary measures (Krebs 2009, 185; Hanrieder and Kreuder-Sonnen 2014). While a relatively novel phenomenon with a yet manageable number of instances, this study submits that IO exceptionalism represents a 'class of events' which is observable across fundamentally different international institutions and issue areas.

This finding matters in at least two important ways. First, as we know from observations of domestic states of emergency, exceptionalism tends to have a lasting impact on a polity's authority structures (see Krebs 2009; Tarrow 2015). It is rarely truly exceptional in the sense that emergency measures would merely be adopted for a limited amount of time before returning to the status quo ante. Often, emergency powers are partially or entirely normalized over time, leaving executive institutions with greater discretion and new competencies on a permanent basis (Gross and Ní Aoláin 2006, 228-43). As shown in this paper, the same holds true for emergency powers of IOs: IO exceptionalism tends to lead to a sustainable empowerment of the institution in question. In fact, the specific postnational conditions in which IO exceptionalism operates even increase the likelihood of ratcheting up IO authority leaps. Hence, emergency politics becomes an important mechanism through which international authority is sustainably expanded 'through crises' - complementing our understanding of punctuated equilibrium models for institutional development.

Second, it raises questions about the normative assessment of the exercise of international authority. The emergency problematique always implies the weighing of partially competing goals and values. Because it comes at a cost to democratic control and constitutionalism, exceptionalism often has a critical connotation. On the other hand, however, emergency action may be seen as functionally appropriate and a measure of last resort to avoid greater harm. ${ }^{3}$ The extraordinarily assertive type of global governance enacted by IO exceptionalism certainly represents a setback in terms of input legitimacy and is at least questionable in terms of legality. In contrast, for IOs that are hampered by historical inefficiencies or political

\footnotetext{
${ }^{2}$ To be sure, the concept of exceptionalism as used here reflects its understanding in critical security studies where it relates to exceptional practices by authority-holders in times of crisis (see, e.g. Neal 2010). It does not relate to special claims of entitlement associated with particular actors as, for example, in 'American exceptionalism.'

${ }^{3}$ For the polar positions in this debate, see Cole (2003) and Posner and Vermeule (2007).
} 
stalemate, emergency politics may represent a virtuous escape route from gridlock. While the normative evaluation of IO exceptionalism may thus be dependent on its situation-specific proportionality, it is another question whether a permanent (self-) empowerment can be justified by an emergency. We will return to this question in the conclusion.

The remainder of this article is structured as follows. Section 2 elaborates on the argument that analyses of mission creep fall short in accounting for the crisisinduced authority expansions which some IOs have witnessed in the past decades. It introduces the constitutional perspective on IOs as an alternative lens to apprehend the changing structures of authority in international institutions. Drawing on constitutional theory of emergency powers and critical security studies, Section 3 extracts the core logic of exceptionalism and discusses the specific shape of emergency politics at the IO level. Section 4 illustrates IO exceptionalism using examples from the UNSC, the WHO, and the EU. Section 5 eventually delves into the question of the longer-term institutional consequences of IO exceptionalism. It specifies drivers for the lock-in of authority leaps and shows their working in the post-exceptionalist development of the institutions mentioned above.

\section{From mission creep to authority leaps}

This section starts by reviewing theoretical approaches to informal task expansions of international institutions. Rational and sociological institutionalists conceive of different types of mission creep, which exclude more direct, abrupt, and discretionary forms of crisis politics. In a second step, the section introduces the constitutional perspective on IOs which lays the foundation for understanding the crisis shifts in IOs' political orders as instances of emergency politics.

\section{Mission creep in crisis?}

There are two main theoretical approaches to the problem of mission creep, one rational and one sociological institutionalist. The rational institutionalist variant has mainly been shaped by the principal-agent (PA) theory of IOs (Nielson and Tierney 2003; Hawkins et al. 2006a). It is based on the conception of IOs as unitary agents working at the behest of their collective member state principal. States delegate governance functions to the IO agent who is supposed to carry out these tasks in their interest. However, IOs are also conceived as actors that pursue their own interests strategically. This allows for the possibility of agency slack, understood as 'independent action by an agent that is undesired by the principal' (Hawkins et al. 2006b, 8).

The PA literature attributes mission creep through agency slack to incomplete contracts and insufficient control mechanisms. Simply put, IOs have a built-in tendency to opt for task expansions when the political/institutional opportunity presents itself $^{5}$ and it depends on the institutional design of oversight and sanctioning mechanisms in the hands of states whether or not they can do so (see also Cortell and Peterson 2006; Lawrence 2008; da Conceição-Heldt 2013).

\footnotetext{
${ }^{4}$ To be sure, this is not to say that the literature is blind to abrupt, large-scale institutional change in general. The argument is that it misses abrupt changes that are informal.

${ }^{5}$ But see Cortell and Peterson's $(2006,256)$ qualification that IO preferences for independent action largely depend on the bureaucracy's staffing rules.
} 
Given principals generally firm control over IO agents, slippage tends to take the form of small-scale incremental policy adjustments which are hard to identify as slack by the principal. This is helped by agent specialization which exacerbates problems of hidden action and hidden information in the bureaucracy as well as environmental uncertainty which makes it difficult for states to assess whether a certain outcome is due to agent misbehavior or some exogenous event (Hawkins et al. 2006b, 24-5). Slack is thus likely when partially autonomous IO agents can exploit ambiguities in the delegation contract and member states either lack the institutional means or the political unity to control or sanction.

The sociological institutionalist approach conceives of IOs as partially autonomous bureaucracies enjoying expert and moral authority over their member states (Barnett and Finnemore 2004). While embodying the promise of rational governance by a depoliticized technocracy, IOs also frequently develop internal bureaucratic cultures which may cause 'organizational pathologies' (Barnett and Finnemore 2004, 38). Because bureaucrats follow routines and standard operating procedures, they may fall into ritualized behavior that constructs a distinct normative environment within the organization detached from its larger social environment. From this perspective, IO mission creep originates in the combination of IOs' bureaucratic culture and their authority to define political agendas. As Barnett and Finnemore $(2004,43)$ put it, 'IOs tend to define both problems and solutions in ways that favor or even require expanded action for IOs.' In their view, bureaucracies thus have a natural tendency to expand in both size and scope of tasks. Moreover, mission creep can also take the form of 'organized hypocrisy' by which IOs react to conflicting material or ideational demands in their environment or to conflicts between external demands and their internal culture (Weaver 2008, 26-31; see also Lipson 2007). To secure necessary material resources and maintain legitimacy, bureaucracies tend to decouple their formal working structures from the actual work activities. This allows concealing inconsistencies between environmental expectations and the practiced organizational culture (Brunsson 1989). Either way, sociological institutionalists envision IO task expansions as slowmoving incremental processes which are mostly oblique and hard to detect for member states and other actors outside the organization.

In both the rationalist and the constructivist variant, mission creep in IOs is thus truly conceived as a creeping process in which supranational institutions gradually 'autonomize' by escaping member state control or by making member states believe in the rationality of their task expansion (see also Koch 2009). How does this conceptualization fare in accounting for the politics of IO empowerment in moments of transboundary crisis? Consider the example of the ECB during the euro crisis. While entrusted with a large amount of independence in carrying out its duties, the Bank's mandate used to be tightly circumscribed and restricted to matters of monetary policy with the aim of securing price stability in the Eurozone (Tuori and Tuori 2014, 28-30). During the crisis, however, the ECB has arguably become 'the most central - and powerful - supranational institution of our times' (Curtin 2017, 29). Two developments stand out in particular. First, by adopting measures such as the Securities Markets Program (SMP) in 2010 and the Outright Monetary Transactions (OMT) program in 2012, the Bank assumed the role of lender of last resort to sovereigns in the Eurozone - a function that the Treaties 
rather explicitly denied the ECB for fear of moral hazard problems. ${ }^{6}$ Then-ECB President Jean-Claude Trichet openly justified the steps as an 'exceptional intervention' due to 'exceptional circumstances' (Trichet 2010) and his successor, Mario Draghi, boldly claimed that the Bank would do 'whatever it takes' to preserve the euro (Draghi 2012). Second, by tying its lending to strict conditionalities - initially in the form of direct individual requests for austerity reforms, later as part of the Troika (Beukers 2013) - the Bank got deeply involved in member states' economic policy, a field for which the Treaties assign exclusive competence to the national level (Dawson and Witte 2013). As a consequence, the ECB, a democratically largely unaccountable non-majoritarian institution, was effectively in the position to decide on the fate of the Eurozone as a whole, to autonomously redistribute financial risk among member states, and to direct national economies in recipient states.

The example does not correspond to the dominant conceptions of mission creep for two main reasons. First, the ECB's expansion of competences was not a creeping process but an abrupt (self-) empowerment for which neither the bureaucratic culture nor the principal control account is sufficient. Other than in the typical cases of slack or pathologies, the Bank's practice was hardly attended by uncertainties about the reasons and purpose for its actions. Also, it did not stay under the political radar but hid in plain sight. It was a necessary part of the ECB's rescue politics to communicate its stepping in as an assertive measure and be widely appreciated to calm the markets. Second, little indicates that the ECB followed a bureaucratic rationality deviating from that of its normative environment or that it slipped through its principals' oversight mechanisms. This is because the example is just not a case of an IO engaging in actions undesired by many or the most important member states. On the contrary, the Bank's interventions were supported, albeit behind the scenes, by most Eurozone governments, including Germany's (see Schelkle 2014). ${ }^{7}$ The conflict line does not run between the IO agent and the state principal, but between the holders of international authority (here: the ECB and powerful member states) and several state and societal authority-addressees. Other than the relationships between states and IO bureaucracies, this relationship is best understood through the lens of constitutional theory.

\section{A constitutional perspective on 10 authority}

Since 1945, IOs have unevenly but consistently gained political authority (e.g. Hooghe and Marks 2017; Zürn 2018). In abstract terms, the exercise of political authority by an IO means that it successfully claims the right to formulate prescriptions, rules, and orders that are, in principle, recognized as binding by the

\footnotetext{
${ }^{6}$ See Art. 123(1) TFEU which states: 'Overdraft facilities or any other type of credit facility with the European Central Bank [...] in favour of [...] central governments, regional, local or other public authorities $[\ldots]$ shall be prohibited, as shall the purchase directly from them by the European Central Bank or national central banks of debt instruments.'

${ }^{7}$ Because the German members of the ECB's Governing Council strongly opposed the Bank's crisis policies, observers have concluded that the ECB's bond-buying programs went against the interests of the most powerful member state. However, this interpretation overlooks the fact that the opposition only reflected the stance of the independent German Bundesbank, not the German government, which in fact has been initially reluctant but eventually supportive of the ECB's actions.
} 
rule-addressees, even though they may go against the short-term interests of some community members (Zürn, Binder, and Ecker-Ehrhardt 2012, 87). Institutionally, we speak of the pooling of authority in IOs when member state bodies such as the EU Council allow for majority votes that may trump the interests of certain member states. And we speak of the delegation of authority to IOs when bureaucratic (such as the UN Secretariat) or political (such as the EU Commission) non-state bodies are granted the competence to take binding decisions (Hooghe and Marks 2015). It is important to note that IO authority is thus not the same as IO autonomy. ${ }^{8}$ Not only in IOs with pooled authority does their direction often remain subject to the influence of powerful states, bringing those states more in the position of authority-holders rather than authority-addressees (Viola, Snidal, and Zürn 2015). This implies that the binary distinction between states and IOs can be misleading in the context of international authority. The more sensible approach is to focus on the relationship between the governors and the governed that may come in different compositions of state, institutional, and individual actors.

A constitutional perspective on IOs regards IOs as legally constituted political orders containing provisions to regulate and limit political authority with regard to the making, implementation, and adjudication of rules (Klabbers 2002, 53-73; Rittberger, Zangl, and Kruck 2012, 73-5). A constitutional perspective does not imply the assumption of normative constitutional principles in liberal or republican terms - it is indifferent to whether or not the organization is democratic or autocratic, discretionary or rule-bound - and is thus to be distinguished from an exercise in constitutionalism. ${ }^{9}$ What the constitutional perspective does, however, is to understand IOs as grounded in basic laws that reflect a minimalist conception of constitutions in that ' $\mathrm{t}$ ] hey lay down the terms of membership and the relation between the members and the community and regulate the institutions' core functions of lawmaking, conflict resolution, and law enforcement' (Milewicz 2009, 418). This is precisely one of the basic functions of IOs' founding treaties. ${ }^{10}$ The constitutional perspective thus treats IOs as simple legal orders that contain secondary rules to define the procedures for rule-setting, rule-implementation, and rule-adjudication, without however implying any normative standard for these procedures (Hart 1994, 79-99; see also Zangl 2006, 26-34). In fact, the normative quality of the procedures is the decisive empirical question which may be addressed through the constitutional perspective.

At the core of any legally constituted political order lies the regulation of the goal conflict between, on the one hand, the freedom and self-determination of individual or collective entities in (world) society, and on the other hand, the political discretion of the wielders of authority to implement collectively binding decisions (see e.g. Ackerman 1993). By entering into a social contract, individuals (or entities) agree to give up formal autonomy in exchange for the provision of

\footnotetext{
${ }^{8}$ The autonomy of an IO bureaucracy can be one (among many) of the sources of recognition for IOs' authority (Barnett and Finnemore 2004), but the concepts are not co-extensive.

${ }^{9}$ See Milewicz $(2009,417-22)$ for a useful distinction of the terms constitution, constitutionalism, and constitutionalization.

${ }^{10}$ IOs' founding treaties legally constitute their political orders as they 'normally outline the organization's mission, establish its various organs and determine the allocation of competences between them. They thus act as a sort of "constitution"' (Rittberger, Zangl, and Kruck 2012, 74; see also: Hurd 2011, 37-55).
} 
collective goods by a superior authority (see also Lake 2010). However, they are wary of the powers that those in authority may wield over them. This is also due to the conflicting preferences authority-holders and addressees display as a consequence of their different social roles (Kreuder-Sonnen and Zangl 2016, 333): Ceteris paribus, rulers prefer the greatest possible freedom of action to assert their (self- or other-regarding) interests in the way they deem appropriate. The ruleaddressees, in contrast, share a preference for self-rule as provided by liberal and republican rights. Since these rights impose constraints on the wielding of authority, the simultaneous strife for political autonomy by authority-holders and authority-addressees is, in principle, incompatible. Political orders reflect precarious compromises regarding this trade-off between the enabling and the constraining functions of constitutions (see Dunoff and Trachtman 2009 on constitutional functions).

From the perspective of authority-holders, the social contract typically implies both vertical and horizontal legal constraints. In the vertical dimension, the exercise of authority may find limits in substantive rights of the rule-addressees which function as prohibitions of certain actions for the rulers. For example, in virtually all modern political orders, the rights to life and physical integrity of the individual function as prohibitions for authority-holders to kill or harm their subjects unless demanding procedural requirements are met. The same holds true for the territorial integrity of the state as the primary target of international authority. Moreover, the rule-setting of authority-holders may be limited by procedural requirements guaranteeing participatory rights of the rule-addressees. That is, by legally premising certain decisions on inclusive procedures for rule-formulation or approval, authority-holders may find their scope of policy discretion circumscribed. In the horizontal dimension, in contrast, authorities' competences are most often functionally delimited and held in check by adjacent institutions. In liberal constitutional states, systems of checks and balances and the separation of powers are to ensure that there is no concentration of power in one authority and that the different nature of legislative, executive, or judicial tasks is reflected in the appropriate composition of the respective organs (Möllers 2013). While hardly any IO has such an elaborate system for the tripartite separation of powers, different IO organs may each still be (and most often are) limited to either executive, legislative, or judicial functions, which set boundaries for their exercise of authority (see generally Mendes and Venzke 2018).

With these distinctions, the constitutional perspective allows for a description of IOs' political orders with a view to the specific regulation and containment of the conflict between authority-holders and authority-addressees. At any given point in time, we can empirically determine the legal structures and practices constituting and constraining IO authority and thus make statements about the constitutional design of their political orders. As should be clear, in both the vertical and the horizontal dimension, constraints can be more or less pronounced, allowing for different levels and configurations of executive discretion, democratic participation, and substantive rights protection. Yet, no matter what the baseline, changes in the constitutional configuration of an IO's political order over time, the ways in which they come about, and the newly emerging power constellations between authorityholders and authority-addressees can become the subject of social scientific inquiry by adopting the constitutional perspective. 
From this perspective, then, the assertive IO crisis responses mentioned earlier appear in a different light. Sticking to the ECB example, it appears that the organization has not engaged in mission creep but carried out a crisis-induced 'authority leap' by lowering the levels of constraints in both the vertical and the horizontal dimension. Horizontally, the Bank expanded its executive discretion into political areas for which its non-majoritarian design was not envisioned in the Treaties. Vertically, it interfered with the rights of its rule-addressees, stripping member states off their fiscal autonomy and interfering with constitutional rights of workers and Unions in recipient countries (Dawson and Witte 2013; FischerLescano 2014). It did so abruptly, with the consent of the most powerful member states, and openly - arguing that its interventions were necessary to cope with the crisis. As will be argued in the following sections, this is emblematic for a postnational form of emergency politics which follows a distinct logic of exceptionalism and has important consequences for the development and our assessment of international authority.

\section{Emergency politics of IOs}

This section is devoted to the conceptualization of crisis-induced IO authority leaps as a post-national form of emergency politics. Drawing on constitutional theory of emergency powers and critical security studies, I first outline the core logic of exceptionalism arguably inhering emergency politics at any given level of governance. In a second step, I then discuss the specific characteristics of exceptionalism at the IO level.

\section{The logic of exceptionalism}

In constitutional theory, the state of exception or state of emergency is understood as a legal institution regulating the suspension of (certain provisions of) the normally applying constitutional order - the state of normalcy (see Dyzenhaus 2006; Gross and Ní Aoláin 2006; Scheuerman 2006; Fatovic 2009). It is logically triggered by an emergency situation - an exceptional threat to the political order - that requires an exceptional response. Somewhat paradoxically, then, the state of exception denotes the legal framework for the suspension of the law. The social scientific view builds on but also differs from this conception. It is less concerned with the constitutional provisions regulating emergencies but focuses more on the political practices and justificatory discourse characterizing emergency rule. Here, the combination of 'exceptional policies and practices, legitimated by claims about exceptional events and circumstances' (Neal 2010, 1), is what is referred to as emergency politics or exceptionalism. More precisely, as White notes, emergency politics is a mode of rule in which actions contravening established norms are defended - often exclusively - as a response to exceptional circumstances that pose some form of existential threat. [...] Necessity rather than consent is the organizing principle' (White 2015b, 302-3). Accordingly, it is independent of both objective circumstances qualifying as emergency and a legal basis for or formal declaration of a state of emergency.

The internal logic of exceptionalism is simple. By rhetorically relating political measures to an existential threat, they become difficult to contest except based on the threat itself. Whether the threat is real or (only) perceived, whether it is 
proactively constructed by political elites or a 'natural' antithesis to the human condition, under the impression of existential crisis, publics tend to accept and even demand that authorities engage in assertive action to avert the threat, even if it reduces the scope of individual freedom (Gross and Ní Aoláin 2006, 220-1; Krebs $2009,185)$. Given the uneven distribution of information and knowledge in favor of executive authorities under conditions of uncertainty, claims about the necessity of political measures to cope with the critical situation are easily accepted. Political contestation regarding, for example, the negative side-effects of the measures on civil liberties, can then be refuted as diversions from the primary - because existential - goal of averting the threat. ${ }^{11}$ Irrespective of whether the political response is purely reactive and in good faith or represents a self-regarding exploitation of the circumstances, exceptionalism involves an expansion of political discretion for executive actors. It thus disrupts the precarious equilibrium in the relationship between authority-holders and authority-addressees and allows for 'authority leaps.'

The formal constitutional denomination for this exceptional increase in executive discretion is the assumption of emergency powers. As a matter of regularity, the assumption of emergency powers implies the adoption of a broader range of functions by executive actors and their encroachment upon rights of the rule-addressees (see, e.g., Scheppele 2010, 134-43). Emergency powers thus expand discretion in both the horizontal and the vertical dimension.

On the horizontal dimension, emergency powers can vary greatly from rather narrow extensions of executive competences via the decree of legislative measures or judicial verdicts to the modification or replacement of the entire constitutional order. The most far-reaching form of emergency powers is what Carl Schmitt called 'sovereign dictatorship' (Schmitt 2014, 112-31), that is, the power to amend, revoke, and even replace completely the pre-existing constitutional order (see also Gross $2000,1845)$. More often, however, emergency powers rather factually undermine the normally valid separation of functions between different organs in the political order as authority-holders expand the scope of their executive competencies or venture into legislative or judicial realms (Gross and Ní Aoláin 2006, 59).

On the vertical dimension, emergency powers can range from a limited interference with the rights of the rule-addressees to complete abrogation of rights and legal protection. The lowest-level intrusive emergency powers interfere with rights only at the procedural, not the substantive level. More intrusive emergency powers suspend the substantive core of certain rights but stop short of affecting the most fundamental (existential) rights of the rule-addressees. Finally, in the most extreme case, emergency powers completely disenfranchise the subjects under their control. $^{12}$

Whatever the concrete configuration in empirical cases, exceptionalism, as understood here, always denotes an exercise of political authority, justified as necessary to cope with an emergency, which expands executive discretion by

\footnotetext{
${ }^{11}$ The essence of this dynamic has been captured in what the securitization literature calls the logic of war' - that is a language game of security which allows for argumentative defense of only one goal, namely survival, and relegates all other purposes to second rank (see Waever 1995, 53-4; Buzan, Waever, and Wilde 1998).

${ }^{12}$ This level of intrusiveness is symbolized by the legal black hole Guantanamo where the detainees were subject to torture and left without access to effective means of judicial review.
} 
assuming new functions and encroaching upon the rights of the rule-addressees. How emergency powers are constituted, that is, whether they are legally conferred or the result of an extra-legal self-empowerment, is an empirical question. Importantly, the justification requirement captures both constitutional and extraconstitutional emergency politics: Formal declarations of an emergency or the invocation of a legal derogation clause imply that the measures which follow are justified in terms of necessity, even without additional verbal expression to that effect. Conversely, even without any formal or legal basis, arguments by authorities that some condition represents an existential threat to the community which can only be averted by the proposed (extraordinary) measures indeed represents a justification in terms of necessity.

In sum, the logic of exceptionalism generally comprises two necessary elements: (1) emergency powers expanding executive discretion both horizontally and vertically and (2) the explicit or implicit justification of the political measures by reference to necessity. While this conceptualization is specific enough to identify cases of exceptionalism and distinguish them from other forms of exercising authority, it is broad enough to capture a wide variety of different models and empirical expressions of emergency politics, be they legal or extra-legal, declared or undeclared, constrained or dictatorial, and domestic or international.

\section{Specificities of 10 exceptionalism}

IO exceptionalism must be understood as a discrete, post-national type of emergency politics, which exhibits a number of distinctive features (see also White 2015b; Scheuerman 2018). They mostly derive from the structural differences between national and international relations of hierarchy and subordination (Zürn 2018). Three concrete observations on the specific shape of IO exceptionalism follow from this:

- First, domestic emergency powers are typically exercised by the executive branch of government in the shadow of coercion. IO emergency powers, in contrast, are acts of international political authority that is based on the acquiescence by the governed. Yet, even if the addressees of international authority recognize an IO's competence to take binding decisions in general, their deference to the authority is certainly not unlimited. It is restricted to a (broad) corridor of practice presumed legitimate for its positive effect on attaining a common good and which does not undermine the vital interests of the community members (Zürn 2018). IOs' dependence on recognition and legitimacy in the eyes of their members is likely to make them wary about offending especially the most powerful among them. The unequal distribution of power among states (and other actors) in the international system should thus have consequences for the direction and effects of international authority in general, and IO exceptionalism in particular (Krisch 2005; Viola, Snidal, and Zürn 2015). Given the extraordinary rise in reach and intrusiveness of IO authority associated with the assumption of emergency powers, it is unlikely that their measures are opposed to the interests of the most powerful member states. Intergovernmental IO organs are typically dominated by the most powerful states and can thus be expected to reflect rather than undermine their interests. To the same effect, supranational IO agents must fear the consequences of acting against the will of the most influential members who could 
(threaten to) sanction the bureaucracy through material (i.e. withdrawal of funds) or immaterial (i.e. questioning the authority) means (Hawkins et al. 2006b, 31-2). The at least implicit consent of the most powerful member states should thus be considered a necessary condition for IO exceptionalism to come about. The effects of IO exceptionalism, then, can be assumed to be asymmetric or stratified across states as a function of the distribution of power among them (see also Viola, Snidal, and Zürn 2015).

- Second, in IO exceptionalism, the locus of authority is not necessarily congruent with the locus of 'sovereignty' in the Schmittian sense (of who decides on the exception). Whereas the ideal-typical domestic emergency regime combined both in a clearly hierarchized institution, IO exceptionalism rests on complex formal and informal, direct and indirect power relations of composite actors (see also White 2015b, 311). Hence, while the concrete emergency measures may formally emanate from the authority of specific IO organs and take the form of their legal instruments, it is a different question whose power and interests are the political drivers behind these decisions. Indeed, IO bureaucracies can more or less autonomously categorize a situation as an exceptional threat and devise emergency measures to overcome it. Yet the same supranational actors may also be informally controlled by powerful states who wish to employ the IO authority to assert their (exceptional) policy preferences internationally (see Stone 2011). We can thus discern three constellations of authority and interests: (1) powerful member state interests enacted by intergovernmental IO bodies (i.e. those composed of member states pooling their authority); (2) institutional interests autonomously enacted by supranational IO bodies (i.e. those composed of international civil servants or policy-makers without formal national allegiance); (3) powerful member state interests enacted by supranational IO bodies.

- Third, IOs' level of political authority is still much smaller than that of states. Also, IOs' political orders are, on average, less constitutionalized than their domestic counterparts. As a corollary, IOs generally lack legal provisions formalizing the resort to emergency powers. At the time of their creation, hardly any IO would have been considered by their designers as powerful enough to warrant strong constitutional constraints - only deviations from which would require the type of 'emergency constitution' (Ackerman 2004) that almost all states have today enshrined in their legal orders, one way or another (Krisch 2010, 45). One of the few organizations with institutional rules akin to an emergency constitution is the UNSC. Chapter VII of the UN Charter practically endows it with extraordinary powers in times of crisis and details the mode for determining the existence of an emergency situation (Art. $39 \mathrm{UNC}$ ) as well as the measures to counter it (Art. 41-42 UNC). Yet even here, neither the actors involved nor the scholarly community recognizes the legal institution of Chapter VII as an emergency constitution and the powers exercised by the Council as exceptional. ${ }^{13}$ The constitutional state of emergency has not yet taken hold as a regulative ideal in international institutions (Schott 2007). As a consequence, IO exceptionalism will typically be more informal than domestic emergency politics. Since there is no formal basis for emergency action beyond the normally valid power constraints, IOs should not be expected to acknowledge that they do in fact exercise emergency powers. More often than not, the

\footnotetext{
${ }^{13}$ For an authoritative example in legal scholarship, see Krisch (2012).
} 
constitutive mode for IO emergency powers will be the extra-legal empowerment of executive actors who might on the one hand admit the peculiarity of their actions in light of a crisis situation, but on the other hand have a strong incentive to deny exceptionality in a legal sense.

In sum, IO exceptionalism follows the same fundamental logic as exceptionalism at any other level of political authority. In distinction from the state model of emergency politics, however, the emergency politics of IOs exhibit three specific characteristics. First, IO emergency measures are stratified in scope and application according to power differentials among the authority-addressees. Second, IO exceptionalism comes in complex institutional configurations which prompt a diffuse relocation of the 'sovereign' power to decide on the exception. Third, in the absence of formal emergency constitutions, IO exceptionalism is typically informal and will often uphold a pretense of normalcy.

\section{Illustrating 10 exceptionalism}

In this section, empirical evidence is provided for the basic existence statement regarding IO exceptionalism in cases of the UNSC, the WHO, and the EU. Given the primarily phenomenological character of this exercise, the case selection chiefly reflects the goal to establish that IO exceptionalism occurs across issue areas and in most diverse institutional settings and is thus in fact a non-idiosyncratic class of events. The cases discussed below cover issue areas as diverse as security, health, and finance; they comprise IOs with different degrees of pooled and/or delegated authority; they vary in terms of the actors most affected by the perceived threat during the respective crises (i.e. the United States, East Asia, EU); and they have different memberships. These differences notwithstanding, they all resorted to practices in line with the logic of exceptionalism. Of course, this case selection strongly limits the scope of inference regarding the conditions under which IO exceptionalism does or does not occur in the first place. This represents an important avenue for future research (see Section 6). The remainder of this article pursues the more modest goal of establishing the existence of IO exceptionalism and showing that it has recurring longer-term consequences for IOs' authority structures.

\section{Global decree-legislation by the UNSC in the wake of 9/11}

After the terrorist attacks of September 11, 2001, the UNSC took a number of unprecedented steps to counter transnational terrorism on a global scale. Led by its most powerful member, the United States, the Council devised a number of exceptional measures. One of these measures was adopted as Resolution 1373 (2001), less than 3 weeks after the attacks and without any public debate. The resolution was extraordinary in several respects. First, it established that international terrorism per se - an abstract and general phenomenon - constitutes a threat to international peace and security. Second, acting under Chapter VII of the UN Charter, the SC imposed a number of legal obligations for all states which have to be translated into amendments to their domestic legislation. This included the duty to criminalize any form of logistic or financial support for terrorists, to freeze funds and financial assets of persons or entities potentially involved in terrorist activities, 
and to tighten border controls and cross-border intelligence sharing (op. paras 1 and 3).

With this act of authority, the Council formally activated its constitutional emergency powers under the Charter that enable it to take exceptional measures in response to threats to the peace (Schott 2007). However, it has been noted that the counter-terrorism measures of the UNSC even surpassed the previously accepted constitutional constraints on its emergency powers. In that sense, it arguably created 'an exception to an already existing exception' (Bianchi 2006, 891-2). It did so by expanding its executive discretion in both the horizontal and the vertical dimension. Horizontally, the UNSC widened the reach of its emergency powers by leaving the terrain of executive regulation and starting to legislate for the international community as a whole (Szasz 2002; Alvarez 2003). ${ }^{14}$ The Council's mandate had so far been interpreted as providing a policing function to intervene in concrete, temporally and geographically confined situations (Koskenniemi 1995; Szasz 2002). As a global executive, its task was to implement abstract norms in specific contexts. With Resolution 1373, however, the UNSC adopted measures that took the form of international laws: obligations of abstract (unrelated to a specific situation), general (for all states), and indefinite character (Rosand 2004, 567; Joyner 2012). As with international conventions and treaties that must be ratified in the domestic context, states do enjoy some flexibility as to the concrete implementation of the provisions of Resolution 1373, but they may not deviate from the substantive core of the directives decided at the international level. Hence, by moving from the application of abstract norms in concrete situation to the decree of such abstract norms itself, the UNSC empowered itself to act as a global legislator.

Vertically, the imposition of international legal obligations by the UNSC undermined the principle of consent upon which international law-making used to be built and thus interfered with the sovereignty rights of UN member states (Elberling 2005, 351). It used to be a fundamental principle of the international legal order that states are free to decide whether or not to accede to a given legal instrument. That is why international treaties and conventions are generally optional and subject to unilateral reservations. It is a reflection of the sovereign equality of states as enshrined in Art. 2(1) UNC that no state may be subjected to rules it has not consented to. By legislating for the international community as a whole, the UNSC suspended this principle. This becomes clear when we take into consideration that Resolution 1373 builds on provisions included in the 1999 International Convention for the Suppression of the Financing of Terrorism which only a minority of UN member states had signed and ratified by September 2001 . To become a party to the Treaty was their sovereign choice. The Council then used its Chapter VII authority to adopt a binding resolution to impose the norms of the Convention on all member states regardless of their position (Bantekas 2003, 326). Several international lawyers concluded that despite the broad scope of discretion accorded to the Council under Chapter VII of the Charter, it had acted ultra vires and 'usurped' political authority (Fremuth and Griebel 2007; Arato 2012; Cohen 2012). On the other hand, the permanent Council members always maintained that

\footnotetext{
${ }^{14}$ Legislation refers to an authority issuing binding norms that take the form of abstract and general laws. In contrast, regulation refers to an authority issuing concrete, issue-specific rules that often serve the purpose of implementing more encompassing laws.
} 
the measures were covered by the powers conferred to it in the Charter and thus impeccable from a legal perspective. As Jean Cohen notes, 'care was taken by the Council to frame the expansive reading of its powers within the discursive limits and mandate of Chapter VII [...]' (Cohen 2012, 271).

The Council's justification for this course of action was implicitly based on political necessity. On the one hand, the UNSC determined a threat to the peace according to Art. 39 UN Charter, which may be interpreted as a declaration of an emergency allowing for extraordinary measures (see Schott 2007). On the other hand, the acutely felt and widely shared impression of crisis which arguably created a moment of 'extraordinary politics' after 9/11 occasioned such a broad acquiescence in the Council's arrogation of competencies that it delivered the permanent members from providing any explicit public justification at all (Bosco 2009, 217). Andrés Franco, then-deputy UN ambassador of Colombia who occupied the country's non-permanent seat on the Council in 2001 reportedly stated: 'Who would dare to say anything in that moment? The context wasn't there for a normal negotiation. It just wasn't conducive for anyone to raise the classical issues about why this resolution should be so strong' (quoted in Bosco 2009, 218). Hence, even if implicit, the emergency rationale pierced through the political reasoning behind the adoption of Resolution 1373.

This instance is a clear example of IO exceptionalism where international authority is assumed by an intergovernmental body at the behest of its most powerful member states. The global legislation by the UNSC was primarily drafted by the United States with occasional assistance from the United Kingdom. In essence, the United States exported their domestic counter-terrorism legislation through the UNSC as a transmission belt. The Bush administration thus externalized the global enactment of their counter-terrorism policy by taking advantage of the Council's authority (Alvarez 2003, 875; Tarrow 2015, 229-30). Only because of the combination of US support and UNSC competence it was possible to create emergency powers that are so far-reaching and intrusive. At the same time, the effects of the measures were highly unequal in terms of adjustment costs. The United States obviously had none, but also the other permanent members, in particular China and Russia, 'whose own attempts to deal with those they too readily described as religious extremist-separatist-terrorists never strayed far beyond strike hard campaigns' (Foot 2007, 500), did not have to go at length to comply with the resolution. Sovereignty costs were higher in weaker Western democracies which had to tighten security laws at the expense of constitutional rights, but consequences were most severe in smaller developing countries whose governments diverted the Council provisions into tools to suppress domestic opposition (Scheppele 2006). As expected, the costs of IO exceptionalism were unequally distributed across addressees according to power differentials.

\section{SARS and the WHO's 'revolution' in global health governance}

In November 2002, a hitherto unknown form of pneumonia emerged: The Severe Acute Respiratory Syndrome (SARS). The disease spread to 32 areas around the world, got 8096 persons infected and 774 of them killed (WHO 2004). At the time of the outbreak, the authority structures of global health governance in the field of infectious disease surveillance and control were marked by a 'Westphalian' 
intergovernmental legal order in which political authority resided almost exclusively with sovereign states (Beigbeder 1998, 15; Fidler 2004a). As reflected in the WHO Constitution and more particularly in the 1969 International Health Regulations (IHR), the supranational branch of the WHO was relegated to the role of an observer and service provider. The most important restriction to its function in combating infectious diseases was that member states held an effective veto over whether the WHO could publicize outbreaks on their territory or not, because the Secretariat was only allowed to disseminate information approved by member states (Zacher and Keefe 2008, 41). For a long time, the organization had been forced to watch the spread of epidemics as a bystander, because it lacked the competence to intervene and the member states refused to authorize such actions.

In the SARS crisis, however, the WHO Secretariat, led by Director-General (DG) Gro Harlem Brundtland, resorted to unprecedented and extraordinarily assertive measures to confront the outbreak. In face of an extremely fast global spread of the disease, the WHO decided to take matters into its hands and imposed itself as the primary decision-making authority during the crisis. Not only did the WHO publicly name and shame member states that failed to comply with its information requirements and recommendations, it even issued travel warnings for the most affected regions without the consent and in some instances even against the explicit will of the member states concerned (Fidler 2004b; Hanrieder and Kreuder-Sonnen 2014; Kamradt-Scott 2015, 94-9). The WHO's crisis reaction thus effectuated an expansion of its executive discretion in both the vertical and the horizontal dimension.

Vertically, the organization's emergency measures clearly interfered with the sovereignty rights of the rule-addressees. Without even involving the affected states in the decision, in April 2003, the WHO issued direct travel warnings recommending passengers with destination to Hong Kong and Guangdong Province of China to postpone all non-essential travel. In the following weeks, it extended the warnings to a total of 10 areas in Canada, China, Hong Kong, and Taiwan. ${ }^{15}$ Particularly China fiercely objected its inclusion on the list and initially even tried to sabotage the WHO's campaign by holding back substantial information on the outbreaks on its territory (Kamradt-Scott 2015, 97-8) - as it was legally entitled to according to the 1969 IHR. Yet while the WHO had no legal or political mandate to intervene in the domestic affairs of its member states, it nevertheless publicly rebuked China for its handling of the SARS outbreak on its territory - formerly (and formally) a sphere of exclusive national competence (see also Cortell and Peterson 2006). Horizontally, the WHO autonomously increased its range of competencies to include the issuance of quasi-administrative regulations in the form of emergency recommendations. By doing so, it sidestepped the intergovernmental World Health Assembly (WHA) which is normally entrusted with the delegation of such competences.

As in the previous case, this assumption of emergency powers was justified by the IO as a political necessity. It was the WHO that first rang the alarm bells by declaring that ' $[t]$ his syndrome, SARS, is now a worldwide health threat' (WHO 2003) and it used this context as a background to frame its measures as inevitable. The WHO thus enacted a fundamental shift in authority structures which has

\footnotetext{
${ }^{15} \mathrm{cf}$. The collection of SARS-related travel advice used by the WHO at http://www.who.int/csr/sars/ travel/en/ (last accessed April 17, 2016).
} 
exclusively been legitimated by the crisis exigencies (see also Hanrieder and Kreuder-Sonnen 2014). As a report in the Washington Post stated retrospectively, '[1]ike the natural if unelected leader of a crowded lifeboat, WHO gave orders that no one wanted to be the first to disobey' (Washington Post 2003).

The WHO case is a clear example of IO exceptionalism where authority is assumed by a supranational IO organ in a more or less autonomous fashion. There are no indications that any member state was involved in setting up the organization's emergency regime over SARS or in devising and authorizing the measures to counter the crisis. The WHO Secretariat acted on its own and in its (supposedly other-regarding) institutional self-interest, dealing with the situation in a way compatible with its overarching ideas and goals (Davies, Kamradt-Scott, and Rushton 2015). However, the case also underscores that supranational IO exceptionalism relies on the acquiescence by the most powerful member states and will thus moderate its effects accordingly. While the policies went against the interests of some rather powerful member states, their reach and intrusiveness were very limited. Also, the emergency measures created no costs for any other powerful member state. In fact, all other powerful states profited from the global public good of health security provided at the expense of China's and Canada's sovereignty rights.

\section{The Troika in the European bailout regime}

During the first 2 years of the euro crisis starting in 2010, Eurozone member states created emergency credit facilities (ECFs) such as the European Financial Stability Facility (EFSF) and the European Stability Mechanism (ESM) in order to provide financial assistance to Eurozone members on the verge of default. Most importantly, every granting of financial assistance was accompanied by strict conditionalities to be implemented by the recipient states. These conditionalities were laid down in Memoranda of Understanding (MoUs) 'negotiated' between the respective state and the so-called Troika (composed of the European Commission, the ECB, and the IMF), which is also responsible for monitoring and steering its implementation. Given their dire need for financial support, no recipient government could seriously afford to refuse the Troika's demands for fiscal austerity. Thus, states like Greece, Portugal, and Ireland received detailed reform lists for politically salient issue areas such as health care, education, and labor law with strong distributional effects.

In their function of emergency governors, the institutions of the Troika expanded their scope of discretion both horizontally and vertically. In the horizontal dimension, especially the ECB assumed new functions exceeding its strictly-confined mandate focusing on price stability (Beukers 2013). More importantly, however, the Troika, as a composite institution, vastly expanded its discretion in the vertical dimension, infringing on both sovereignty and individual rights. First, the Troika partially replaced the legislature in the states subject to its tutelage. Most obviously, it seized legislative powers from the Greek parliament when imposing the rule to review and potentially veto any piece of legislation relating to economic and financial issues as a condition for releasing the third aid package in 2015 (European Commission 2015, 4). But already before, the Troika had demanded complete overhauls of labor and employment law as well as cutbacks of public-goods provisions from debtor states - demands that were 
essentially non-negotiable and thus factually suspended these countries' fiscal sovereignty and budgetary autonomy (Dawson and Witte 2013, 825). Second, the Troika's emergency powers also interfere with individual and collective economic and social rights (Fischer-Lescano 2014; Salomon 2015). By directing far-reaching cutbacks in social welfare and restricting public health care, for example, the Troika measures curtail the rights to social security and health (Fischer-Lescano 2014, 4852). Moreover, the MoUs 'undermine labor and trade union rights by, for example, laying down obligations for minimum wage reductions and wage-setting restrictions, the lowering of standards of protection against unfair dismissal, and the suspension of collective bargaining agreements' (Kreuder-Sonnen 2016, 1356; see Fischer-Lescano 2014, 42-8; Salomon 2015).

Both member state leaders and representatives of the supranational institutions justified the whole bailout setup as 'exceptional measures for exceptional times' (see, e.g. Barroso 2011). German Chancellor Angela Merkel even claimed that the Greek bailout with all its consequences was based on 'an ultima ratio, an emergency situation' the existence of which had been 'determined by the European Central Bank, the European Commission, and the International Monetary Fund' (Merkel 2010; author's translation). Thus, the Troika's establishment and its discretionary exercise of authority conform to the logic of exceptionalism.

Where is political responsibility to be located in this case? As described earlier, the holder of emergency powers is a collective actor composed of supranational IO bodies: the Troika. However, the agencies composing the Troika did not arrogate these emergency competences by way of self-empowerment. Arguably, the establishment and empowerment of the Troika was the result of an 'informal delegation' by the members of the EFSF with Germany leading the way, mandating the institutions to execute austerity reforms in the states receiving financial assistance. Hence, it is an example of IO exceptionalism where authority is assumed by supranational IO organs but at the behest of the most powerful member states. Indeed, the Troika is not a completely submissive (collective) agent of its collective principal. Its institutions have their own political ideas and it enjoys some discretion as to the concrete measures it asks from governments under a support program. Yet the impetus for both pushing through harsh austerity measures and for lifting so many legal constraints on these measures came from the (paying) members of the EFSF. Arguably, they tried to employ the technocratic supranational authority of Commission, ECB, and IMF to assert their (exceptionalist) preferences (see also Henning 2017). Hence, while carried out by the Troika, the exceptionalist practice was nevertheless state-led and working at the discretion of the most powerful among them. This also implied an extremely uneven distribution of adjustment costs emanating from the emergency measures. While the powerful creditor countries had to lend taxpayer money to fund the rescue packages, the debtor countries were the ones to shoulder deep institutional transformations and the enormous social, economic, and democratic costs which came along with them (see also Schimmelfennig 2015).

\section{The consequences of 10 exceptionalism: progressive empowerment?}

For as long as the concepts of the state of exception and emergency powers existed, they have been attended by fears of normalization, that is, that the originally exceptional government powers and oppressive policies are not relinquished by the 
power-holders but become permanent features of political life (see also Agamben 2005). In fact, the tendency of normalization, sometimes extension, of emergency powers over time, space, or organizational level is an empirical finding of comparative studies of domestic emergency politics (International Commission of Jurists 1983; Krebs 2010; Tarrow 2015; but see also Posner and Vermeule 2007, 131-56). In this section, I argue that this ratchet effect is also a possibility that pertains to IO exceptionalism and thus represents a mechanism by which crisisinduced IO authority leaps may lead to the sustainable empowerment of IOs. It starts by outlining basic theoretical drivers of normalization, in particular as they relate to IO exceptionalism. In the second step, the post-crisis institutional developments of the UNSC, the WHO, and the EU are showcased. As in the previous section, the goal here cannot be to settle the question under what conditions the ratchet effect occurs in the wake of the assumption of emergency powers by IOs. The more modest ambition is to show that it is in fact a mechanism of enduring IO empowerment that may occur in most dissimilar institutional, normative, and power settings as represented by the earlier cases.

\section{Normalization of emergency powers: the ratchet effect}

In the literature on the consequences of domestic exceptionalism, the ratchet effect is commonly conceived as the process by which emergency politics creates a slippery slope of precedents which enables executives to uphold their extended powers and cast civil liberties in increasingly circumscribed terms. The underlying rationale is that 'government and its agents grow accustomed to the convenience of emergency powers. Once they have experienced the ability to operate with fewer restraints and limitations they are unlikely to be willing to give up such freedom' (Gross and Ní Aoláin 2006, 230). This does not mean that the normalization of emergency powers is an automatism. More often than not, the disruption of the constitutional balance that emergency politics effectuates sets in motion an episode of contention between those empowered and those disempowered by exceptionalism (Tarrow 2015). While the former have an incentive to push for normalization, the latter have an incentive to push for rollback. With whose preferences the outcome of this struggle will eventually be in line depends on the power resources these actors have at their disposal.

There are a number of factors, however, which are frequently invoked to argue that the proponents of normalization have a competitive advantage from the start and should thus be expected to prevail more frequently. In the domestic context, one important aspect is information asymmetries in favor of executive actors inclined to uphold extended discretion (Bonner 1985, 49). Often, the executive has partially exclusive access to information (e.g. secret intelligence) on which the determination of an emergency may be based. Proponents of rollback thus often lack the factual basis for making the successful claim that the empirical conditions warranting emergency powers are no longer in place or that the emergency measures are disproportionate. Relatedly, a second aspect is the tendency of courts to defer to the judgment of the executive in times of crisis - potentially for fear of striking down essentially necessary measures to counter an emergency they do not fully apprehend (Scheppele 2012). As a consequence, courts may give a constitutional blessing to extraordinary means by which exceptionality is turned into 'authoritarian legality' (Diab 2015, 86-93) and thus becomes even harder to 
reverse. Third, an institutional driver is the status quo bias of legislative institutions and the lock-in effects of political decisions adopted during emergencies. Once a state's security apparatus is ramped up, it becomes difficult to unmake, on the one hand because institutional self-interest protects it from the inside, and, on the other hand, because high majority hurdles for new legislation and in particular constitutional amendments protect it from the outside (Friedberg 2000, 30-3; Gross 2003, 1090-6).

With slight adaptations, these factors also travel to the context of IO exceptionalism. In fact, in some dimensions, the specificities of emergency politics at the level of IOs even reinforce the inclination of exceptional powers to become permanent. First, and most importantly, in IOs, institutional power is distributed highly unequally to the benefit of actors favoring normalization. As argued above, IO exceptionalism is premised on the impetus, consent, or at least acquiescence of the most powerful states parties to the IO in question. These states are thus typically in the role of authority-holders rather than authority-addressees and therefore have an incentive to champion the perpetuation of extended IO discretion. ${ }^{16}$ As the actors with the greatest formal and informal institutional power resources, they may be able to formally enshrine the new powers through institutional adaptation or informally uphold them by obstructing attempts at their reversal (see, in general, Hanrieder 2014). Of course, the institutional power disparity may vary in magnitude, but its distribution can be expected to tilt toward ratchet as matter of regularity. This bias in favor of continuity and normalization is further reinforced by IOs' institutional rules - especially unanimity and supermajority requirements for formal agreements - that generate many veto players and blocking minorities which tend to shelter institutional choices from reversal (Scharpf 1988).

Second, the malleability of international law increases the power of precedents and further reduces the likelihood of judicial rollback. 'International law is weakly institutionalized; international adjudication is fragmented and non-compulsory; enforcement of international law is weak; and the mechanism for changing the law cumbersome [...]' (Vinx 2013, 91). International legal norms are also more frequently subject to interpretive development. Both customary and positive law may change through practice that is apparently rule-breaking but collectively supported as a desirable improvement over the existing language, thus transforming noncompliance into a revision of the law (Hurd 2014). In this setting, transgressions are not easily identifiable, the underlying acts of authority are difficult to challenge on purely legal grounds - further complicating the work of international courts and inciting deference to political pressure - and they thus establish precedents on which to base future action. In sum, the international legal environment in which IO exceptionalism operates provides the proponents of normalization with a more favorable political opportunity structure than its opponents.

\section{Exceptions becoming the rule: the normalization of 10 authority leaps}

A trend toward normalization is visible in all three cases of IO exceptionalism introduced earlier:

\footnotetext{
${ }^{16} \mathrm{Or}$, at the very least, they should not be expected to actively oppose the normalization of IO emergency powers.
} 
- The UNSC's emergency measures enacted by Resolution 1373 are still in place today. Moreover, the Council used its self-set precedent after 9/11 to more generally assume legislative powers beyond its executive functions (Cohen 2012, 277). Despite initial resistance, with Resolutions 1540 (2004) and 2178 (2014) the UNSC simply reenacted structurally similar sets of legislative measures in areas pertaining to the non-proliferation of weapons of mass destruction to non-state actors and the so-called foreign fighters for the Islamic State (ISIS/ISIL), without trying to acquire formal legal authorization. Over time, global legislation has become an accepted new competence in the arsenal of the Council's crisis reaction tools (Heupel 2014). The most recent enactment of this emergency power is represented by Resolution 2396 (2017) that concretizes the foreign fightersresolution through further global legislation on border security, information sharing, and criminal justice. For better or worse, the exception after 9/11 has led to a permanent empowerment of the Council to impose globally binding and indefinite obligations in response to threats to the peace.

- In the case of the WHO, its exceptional (self-) empowerment during the SARS crisis led to the formal institutionalization of an emergency regime governing Public Health Emergencies of International Concern (PHEICs), which has remained the WHO's legal basis for emergency action ever since. In 2005, the WHA adopted a revised version of the IHR providing the DG and its new Emergency Committee with the ability to autonomously decide on the existence of a PHEIC and on the measures to be recommended to member states in response (see generally Fidler 2005). In stark contrast to the pre-SARS situation where the WHO had hardly any authority to guide international efforts to combat infectious disease outbreaks, its assumption of emergency powers in 2003 led to permanent authority shift in global health (Davies, Kamradt-Scott, and Rushton 2015). The WHO has made use of its expanded competences, for instance, during the H1N1 influenza pandemic in 2009 and the outbreak of the Zika virus in 2016, while it famously failed to live up to expectations during the 2014 Ebola outbreak.

- While the EU case is still more of a moving target as the post-crisis institutional development has yet to be concluded, most evidence indicates that the European 'bailout regime' is also set on a path of normalization (also White 2015a). Partially, constitutional accommodation of the initially extra-legal bailouts has taken place by way of treaty amendment in 2011 [Art. 136(3) TFEU] allowing the creation of the ESM ex post and constitutionalizing the principle of 'strict conditionality.' In other parts, the Troika's emergency powers simply persist - more or less contested. For example, it still holds a veto over any piece of legislation passed in the Greek parliament. Finally, also proposals for a permanent European Monetary Fund (EMF) imply extended powers for at least the Commission and the ECB in supervising and implementing conditionalities (Financial Times 2017).

The processes leading to the respective forms of normalization reflect the above theoretical drivers to varying degrees. The UNSC's arrogation of legislative authority seems to be mostly a matter of institutional power and favorable political context conditions. In the run-up to the adoption of Resolution 1540 (2004), the first reiteration of the Council's decree-legislation after 9/11, a sizeable number of UN member states expressed their rejection of the Council's assumption of legislative powers. Almost entirely comprised members of the Non-Aligned 
Movement and including middle powers such as Brazil, India, and Pakistan, this group of states advocated a rollback of the Council's emergency powers. In particular, they argued that global legislation was outside the remit of the UNSC's authority according to the Charter, that the Council infringed on the sovereignty rights of other UN members, and that it should not be entrusted with the double role of rule-setter and rule-enforcer (UNSC 2004). However, they lacked the bargaining power and institutional leverage to really challenge the Council's stance. The permanent members were both the greatest beneficiaries of the new discretion - each following their own counter-terrorist agenda (Foot 2007, 500) and the institutionally most powerful actors. As they enjoy the privilege of veto power, they can always block the amendment or revocation of actions the Council has already ordered or authorized. Besides a few concessions regarding the wording and structure of the text, the resolution remained largely unaltered. Legislative authority of the SC has thus become a sustained reality that apparently fewer and fewer states see the point in contesting. In the context of the adoption of the foreign fighters-resolution in 2014, there were hardly any critical voices outside academic circles.

The legal normalization of the WHO's emergency powers in the wake of the SARS crisis seems to be mostly a matter of the power of precedents. After years of stagnant negotiations over a revision of the IHR, the WHO's assertive crisis management created facts on the ground that member states needed to accommodate. With few exceptions, the results of the WHO's emergency interventions - the achievement of ending human-to-human transmission only a few months after the discovery of the disease - were seen by most states and the broader international public as a success story (Kamradt-Scott 2015, 100). Hence, the WHO was in a much better argumentative position than before the outbreak: for promoting the contours of its IHR revision proposal, it could now point to SARS as the prototypical danger associated with emerging infectious diseases that needed strong supranational response mechanisms. Additionally, it could invoke its own emergency measures as an example of how to successfully contain a global health crisis. In effect, all member states could be convinced to (sometimes grudgingly) approve the legalizations of the WHO's emergency regime in the new IHR.

Finally, the preliminary persistence of the European bailout regime can be traced to a combination of the institutional power distribution and the consequences of judicial deference. The ECFs as well as the institution and operation of the Troika have been criticized and contested from a diverse spectrum of political opposition. Simply put, fiscal assistance was chiefly resisted by right-wing forces in the donor countries, whereas the Troika conditionalities were resisted by left-wing forces in the recipient states (e.g. Kousis 2014). Both advocated a rollback of different aspects of the emergency regime. However, a phalanx of EU institutions and powerful member states protected the new political discretion they had won by way of exceptionalism (Niemann and Ioannou 2015, 209-12; Schimmelfennig 2015). In parts, it was even ratcheted up and institutionalized by way of treaty amendment. The most delicate challenge to the regime was levelled at it outside the realm of political negotiation, however. In the so-called Pringle case of 2012, an Irish parliamentarian obtained a preliminary reference of the Irish Supreme Court to the Court of Justice of the EU (CJEU) questioning the legality of the ESM. But amidst an ongoing crisis and under enormous public and political 
pressure, the CJEU took no time to find legal reasons for why the emergency measures could be upheld (Everson 2015, 480). It approved the establishment of the ESM and the treaty amendment by reference to an all-encompassing telos, namely the 'financial stability of the euro area as a whole' and premised its operation on the continued imposition of strict conditionalities - implemented by the Troika. Arguably, the Court's deference thus had the effect of 'sanctifying constitutionally the innovations which legal and institutional experimentation in the management of the Eurozone crisis had brought about' (Tuori and Tuori 2014, 149).

\section{Conclusion}

This article has introduced the concept of IO exceptionalism to understand crisisinduced authority leaps in IOs. Adopting a constitutional perspective on international authority, abrupt changes in the relationship between authority-holders and authority-addressees, in particular the expansion of executive discretion with concomitant rights incursions justified by necessity, have been recast as instances of IO emergency politics. Not only does the phenomenon represent a class of events occurring across a diverse range of policy fields and institutional designs, but it also has important long-term consequences for IOs' authority structures. For just as in the domestic context, IO exceptionalism tends toward normalization. Whether through power or precedent, the once exceptional powers are often made permanent features of the IOs' political order. IO exceptionalism and its subsequent ratcheting up thus highlight a mechanism of authority expansions at the IO level that the IR literature on IOs' institutional development has so far overlooked.

This finding raises an immediate normative concern: Given the limitations on individual/sovereignty rights and participation imposed by IO exceptionalism, it invites critical reflections on how international authority is exercised in times of crisis. As hinted at in the introduction, however, it would be premature to condemn all emergency politics while applauding all constitutional politics in an absolute manner. Most theory on emergency powers that is not constitutionally absolutist holds the view that the normative legitimacy of exceptionalism depends on the means-ends proportionality of the adopted measures (see, e.g., Ackerman 2004). Incursions on the input dimension of democratic legitimacy need to be offset by benefits on the output dimension. That is, to be legitimate, emergency politics must be measures of last resort creating critical policy effects that could not be achieved with less costly measures. While some cases, such as the WHO's intervention during the SARS crisis, would thus seem more and others, such as the Troika's austerity measures, less legitimate according to this standard, the overall evaluation also has to factor in the permanent authority transfers that are engendered by IO exceptionalism. Proportionality can only legitimize truly exceptional measures. Its longer-term consequences must be assessed by the mode of constitutional change through which they are produced. To be normatively justifiable, permanent authorizations require at least some form of democratic legitimacy (see also Patberg 2016). The often tacit and power-driven ratchet effects in the wake of IO exceptionalism pose a serious challenge to this standard.

Not least because of the partially daunting normative consequences of IO exceptionalism, it is thus important to gain a better understanding of the 
occurrence and outcome of the phenomenon in future research. First and foremost, more knowledge is required about the conditions under which IO exceptionalism emerges in the first place. There have been many transboundary crises in the past decades that could have given rise to assertive supranational intervention but did not. In other instances, IOs did intervene but were able to do so without resorting to emergency powers. When exactly IOs go exceptional remains an open question. Finding an answer will also help to specify more clearly the scope conditions for the phenomenon in general. Second, it remains to be explored if and how the ratchet effect can be averted. The normalization of emergency powers is a probabilistic tendency, not an institutional automatism (see also Krebs 2009). When will a coalition of actors be powerful enough to effectuate a rollback against the preference of the actors benefitting from the emergency powers?

Acknowledgments. Earlier versions of this paper were presented at the 2017 ISA Convention in Baltimore and the 2017 Conference of the IR Section of the German Political Science Association in Bremen as well as in seminars at the ARENA Centre for European Studies in Oslo, Nuffield College in Oxford, LMU Munich, and WZB Berlin Social Science Center. For valuable comments and criticism, I would like to thank the participants in these forums as well as Kenneth Abbott, Jelena Cupac, Tom Dannenbaum, Janina Dill, John Erik Fossum, Tine Hanrieder, Berthold Rittberger, Vivian Schmidt, Sidney Tarrow, Rhianna Vonk, Bernhard Zangl, and Michael Zürn. I am grateful to Joia Buning, Felix Ruechardt, and Johannes Scherzinger for valuable research assistance.

\section{References}

Ackerman, Bruce. 1993. We the People, Volume 1: Foundations. Cambridge: Harvard University Press.

Ackerman, Bruce. 2004. “The Emergency Constitution.” The Yale Law Journal 113(5):1029-91.

Agamben, Giorgio. 2005. State of Exception. Chicago: University of Chicago Press.

Alvarez, José E. 2003. "Hegemonic International Law Revisited." American Journal of International Law 97:873-88.

Arato, Julian. 2012. "Constitutionality and Constitutionalism Beyond the State: Two Perspectives on the Material Constitution of the United Nations." International Journal of Constitutional Law 10(3):627-59.

Bantekas, Ilias. 2003. "The International Law of Terrorist Financing." American Journal of International Law 97:315-33.

Barnett, Michael, and Martha Finnemore. 2004. Rules for the World: International Organizations in Global Politics. Ithaca: Cornell University Press.

Barroso, José M. D. 2011. "Statement by President Barroso at the press conference following the meeting of the Heads of State or Government of the euro area”, October 27. Accessed December 12, 2018. http:// europa.eu/rapid/press-release_SPEECH-11-713_en.htm?locale=en.

Beigbeder, Yves. 1998. The World Health Organization. International Organization and the Evolution of World Society 4. The Hague: Nijhoff.

Beukers, Thomas. 2013. "The New ECB and Its Relationship with the Eurozone Member States: Between Central Bank Independence and Central Bank Intervention." Common Market Law Review 50(6):15791620.

Bianchi, Andrea. 2006. "Assessing the Effectiveness of the UN Security Council's Anti-terrorism Measures. The Quest for Legitimacy and Cohesion.” European Journal of International Law 17(5):881-919.

Bonner, David. 1985. Emergency Powers in Peacetime. Modern Legal Studies. London: Sweet and Maxwell.

Bosco, David L. 2009. Five to Rule Them All: The UN Security Council and the Making of the Modern World. Oxford: Oxford University Press.

Brunsson, Nils. 1989. The Organization of Hypocrisy: Talk, Decision, and Actions in Organizations. New York: John Wiley \& Sons.

Buzan, Barry, Ole Waever, and Jaap de Wilde. 1998. Security: A New Framework for Analysis. Boulder: Lynne Rienner. 
Cohen, Jean L. 2012. Globalization and Sovereignty: Rethinking Legality, Legitimacy and Constitutionalism. Cambridge: Cambridge University Press.

Cole, David. 2003. Enemy Aliens: Double Standards and Constitutional Freedoms in the War on Terrorism. New York: New Press.

Cortell, Andrew P., and Susan Peterson. 2006. "Dutiful Agents, Rogue Actors, or Both? Staffing, Voting Rules, and Slack in the WHO and WTO." In Hawkins, Lake, Nielson, and Tierney 2006:255-80.

Curtin, Deirdre. 2017. “'Accountable Independence' of the European Central Bank: Seeing the Logics of Transparency.” European Law Journal 23(1-2):28-44.

da Conceição-Heldt, Eugénia. 2013. "Do Agents "Run Amok"? A Comparison of Agency Slack in the EU and US Trade Policy in the Doha Round." Journal of Comparative Policy Analysis 15(1):21-36.

Davies, Sara E., Adam Kamradt-Scott, and Simon Rushton. 2015. Disease Diplomacy: International Norms and Global Health Security. Baltimore: Johns Hopkins University Press.

Dawson, Mark, and Floris de Witte. 2013. "Constitutional Balance in the EU after the Euro-Crisis." Modern Law Review 76(5):817-44.

Diab, Robert. 2015. The Harbinger Theory: How the Post-9/11 Emergency Became Permanent and the Case for Reform. New York: Oxford University Press.

Draghi, M.. 2012. "Speech by Mario Draghi, President of the European Central Bank at the Global Investment Conference in London", July 26. Accessed December 12, 2018. https://www.ecb.europa.eu/ press/key/date/2012/html/sp120726.en.html.

Dunoff, Jeffrey L., and Joel P. Trachtman. 2009. "A Functional Approach to International Constitutionalization." In Ruling the World? Constitutionalism, International Law, and Global Governance, edited by Jeffrey L. Dunoff, and Joel P. Trachtman, 3-35. Cambridge: Cambridge University Press.

Dyzenhaus, David. 2006. "The State of Emergency in Legal Theory." In Global Anti-Terrorism Law and Policy, edited by Victor V. Ramraj, 65-89. Cambridge: Cambridge University Press.

Elberling, Björn. 2005. "The Ultra Vires Character of Legislative Action by the Security Council." International Organizations Law Review 2(2):337-60.

European Commission. 2015. "Memorandum of Understanding Between the European Commission Acting on Behalf of the European Stability Mechanism and the Hellenic Republic and the Bank of Greece," August 19. Accessed December 12, 2018 https:/ec.europa.eu/info/sites/info/files/ 01_mou_20150811_en1.pdf.

Everson, Michelle. 2015. "An Exercise in Legal Honesty: Rewriting the Court of Justice and the Bundesverfassungsgericht.” European Law Journal 21(4):474-99.

Fatovic, Clement. 2009. Outside the Law: Emergency and Executive Power. Johns Hopkins Series in Constitutional Thought. Baltimore: Johns Hopkins University Press.

Fidler, David P. 2004a. "Constitutional Outlines of Public Health's "New World Order." Temple Law Review 77(2):247-90.

Fidler, David P. 2004b. SARS: Governance and the Globalization of Disease. New York: Palgrave Macmillan.

Fidler, David P. 2005. "From International Sanitary Conventions to Global Health Security: The New International Health Regulations." Chinese Journal of International Law 4(2):325-92.

Financial Times. 2017. "Brussels' bailout fund plan riles EU member states." Financial Times, December 4. Accessed April 30, 2018. https://www.ft.com/content/c34d6ff6-d6af-11e7-a303-9060cble5f44.

Fischer-Lescano, Andreas. 2014. Human Rights in Times of Austerity Policy: The EU Institutions and the Conclusion of Memoranda of Understanding. Schriftenreihe des Zentrums für Europäische Rechtspolitik 68. Baden-Baden: Nomos.

Foot, Rosemary. 2007. "The United Nations, Counter Terrorism, and Human Rights: Institutional Adaptation and Embedded Ideas." Human Rights Quarterly 29(2):489-514.

Fremuth, Michael, and Jörn Griebel. 2007. "On the Security Council as a Legislator: A Blessing or a Curse for the International Community?” Nordic Journal of International Law 76:339-61.

Friedberg, Aaron L. 2000. In the Shadow of the Garrison State: America's Anti-Statism and Its Cold War Grand Strategy. Princeton Studies in American Politics. Princeton: Princeton University Press.

Gross, Oren. 2000. "The Normless and Exceptionless Exception: Carl Schmitt's Theory of Emergency Powers and the "Norm-Exception" Dichotomy." Cardozo Law Review 21:1825-67.

Gross, Oren. 2003. "Chaos and Rules: Should Responses to Violent Crises Always Be Constitutional?" The Yale Law Journal 112(5):1011-1134. 
Gross, Oren, and Fionnuala Ní Aoláin. 2006. Law in Times of Crisis: Emergency Powers in Theory and Practice. Cambridge: Cambridge University Press.

Hanrieder, Tine. 2014. "Gradual Change in International Organisations: Agency Theory and Historical Institutionalism." Politics 34(4):324-33.

Hanrieder, Tine, and Christian Kreuder-Sonnen. 2014. "WHO Decides on the Exception? Securitization and Emergency Governance in Global Health." Security Dialogue 45(4):331-48.

Hart, H. L. A. 1994. The Concept of Law, 2nd ed. Clarendon law series. Oxford: Oxford University Press.

Hawkins, Darren Greg, David A. Lake, Daniel L. Nielson, and Michael J. Tierney. eds 2006a. Delegation and Agency in International Organizations. Political Economy of Institutions and Decisions. Cambridge: Cambridge University Press.

Hawkins, Darren Greg, David A. Lake, Daniel L. Nielson, and Michael J. Tierney. 2006b. "Delegation Under Anarchy: States, International Organizations, and Principal-Agent Theory." In Hawkins, Lake, Nielson, and Tierney 2006:3-38.

Heath, J. Benton. 2016. "Global Emergency Power in the Age of Ebola." Harvard International Law Journal 57(1):1-47.

Henning, C. Randall. 2017. Tangled Governance: International Regime Complexity, the Troika, and the Euro Crisis. Oxford: Oxford University Press.

Heupel, Monika. 2014. "Security Council Legislation in Counter-Terrorism." In The Security Council as Global Legislator, edited by Vesselin Popovski and Trudy Fraser, 124-42. Routledge Global Institutions Series 85. London, New York: Routledge.

Hooghe, Liesbet, and Gary Marks. 2015. "Delegation and Pooling in International Organizations." Review of International Organizations 10(3):305-28.

Hooghe, Liesbet, Gary Marks, Tobias Lenz, Jeanine Bezuijen, Besir Ceka, and Svet Derderyan. 2017. Measuring International Authority: A Postfunctionalist Theory of Governance, Volume III. Oxford: Oxford University Press.

Hurd, Ian. 2007. After Anarchy: Legitimacy and Power in the United Nations Security Council. Princeton: Princeton University Press.

Hurd, Ian. 2011. International Organizations: Politics, Law, Practice. Cambridge: Cambridge University Press.

Hurd, Ian. 2014. "The UN Security Council and the International Rule of Law." Chinese Journal of International Politics 7(3):361-79.

International Commission of Jurists. 1983. "States of Emergency: Their Impact on Human Rights." Accessed December 12, 2018 https:/www.icj.org/wp-content/uploads/1983/01/states-of-emergencythematic-report-1983-eng.pdf.

Johnson, Tana. 2014. Organizational Progeny. Why Governments are Losing Control Over the Proliferating Structures of Global Governance. Oxford: Oxford University Press.

Joyner, Daniel. 2012. "The Security Council as a Legal Hegemon." Georgetown Journal of International Law 43(2):225-57.

Kamradt-Scott, Adam. 2015. Managing Global Health Security: The World Health Organization and Disease Outbreak Control. Basingstoke: Palgrave Macmillan.

Klabbers, Jan. 2002. An Introduction to International Institutional Law. New York: Cambridge University Press.

Koch, Martin. 2009. "Autonomization of IGOs." International Political Sociology 3(4):431-48.

Koremenos, Barbara, Charles Lipson, and Duncan Snidal. 2001. "The Rational Design of International Institutions." International Organization 55(4):761-799.

Koskenniemi, Martti. 1995. "The Police in the Temple: Order, Justice and the UN: A Dialectical View." European Journal of International Law 6:325-48.

Kousis, Maria. 2014. "The Transnational Dimension of the Greek Protest Campaign Against Troika Memoranda and Austerity Policies, 2010-2012." In Spreading Protest: Social Movements in Times of Crisis, edited by Donatella Della Porta, and Alice Mattoni, 137-70, ECPR - Studies in European political science. Colchester: ECPR Press.

Krebs, Ronald R. 2009. "In the Shadow of War: The Effects of Conflict on Liberal Democracy." International Organization 63(1):177-210. 
Krebs, Ronald R. 2010. "International Conflict and the Constitutional Balance: Executive Authority After War." In In War's Wake: International Conflict and the Fate of Liberal Democracy, edited by Elizabeth Kier, and Ronald R. Krebs, 187-210. New York: Cambridge University Press.

Kreuder-Sonnen, Christian. 2016. "Beyond Integration Theory: The (Anti-)Constitutional Dimension of European Crisis Governance." JCMS: Journal of Common Market Studies 54(6):1350-66.

Kreuder-Sonnen, Christian, and Bernhard Zangl. 2015. "Which Post-Westphalia? International Organizations Between Constitutionalism and Authoritarianism." European Journal of International Relations 21(3):568-94.

Kreuder-Sonnen, Christian, and Bernhard Zangl. 2016. "Varieties of Contested Multilateralism: Positive and Negative Consequences for the Constitutionalization of Multilateral Institutions." Global Constitutionalism 5(3):327-43.

Krisch, N. 2005. "International Law in Times of Hegemony: Unequal Power and the Shaping of the International Legal Order." European Journal of International Law 16(3):369-408.

Krisch, Nico. 2010. Beyond Constitutionalism: The Pluralist Structure of Postnational Law. Oxford: Oxford University Press.

Krisch, Nico. 2012. "Chapter VII Powers: The General Framework." In The Charter of the United Nations: A Commentary, edited by Bruno Simma, Georg Nolte, Daniel-Erasmus Khan, and Andreas Paulus, 1237-71. Oxford: Oxford University Press..

Lake, David A. 2010. "Rightful Rules: Authority, Order, and the Foundations of Global Governance." International Studies Quarterly 54(3):587-613.

Lawrence, Robert Z. 2008. "International Organisations: The Challenge of Aligning Mission, Means and Legitimacy." The World Economy 31(11):1455-1470.

Lipson, Michael. 2007. "Peacekeeping: Organized Hypocrisy?" European Journal of International Relations 13(1):5-34.

Mendes, Joana, and Ingo Venzke. eds. 2018. Allocating Authority: Who Should Do What in European and International Law?. Oxford: Hart Publishing.

Merkel, Angela. 2010. "Regierungserklärung von Bundeskanzlerin Merkel zu den Hilfen für Griechenland”, May 5. Accessed December 12, 2018. http://www.bundesregierung.de/ContentArchiv/DE/Archiv17/ Regierungserklaerung/2010/2010-05-05-merkel-erklaerung-griechenland.html.

Milewicz, Karolina. 2009. "Emerging Patterns of Global Constitutionalization: Toward a Conceptual Framework." Indiana Journal of Global Legal Studies 16(2):413-36.

Möllers, Christoph. 2013. The Three Branches: A Comparative Model of Separation of Powers. Oxford: Oxford University Press.

Neal, Andrew W. 2010. Exceptionalism and the Politics of Counter-Terrorism: Liberty, Security, and the War on Terror. Routledge Studies in Liberty and Security. London: Routledge.

Nielson, Daniel L., and J. Tierney Michael. 2003. "Delegation to International Organizations: Agency Theory and World Bank Environmental Reform." International Organization 57(2):241-76.

Niemann, Arne, and Demosthenes Ioannou. 2015. "European Economic Integration in Times of Crisis: A Case of Neofunctionalism?” Journal of European Public Policy 22(2):196-218.

Patberg, Markus. 2016. "Against democratic intergovernmentalism. The case for a theory of constituent power in the global realm." International Journal of Constitutional Law 14(3):622-638.

Posner, Eric A., and Adrian Vermeule. 2007. Terror in the Balance: Security, Liberty, and the Courts. New York: Oxford University Press.

Rittberger, Volker, Bernhard Zangl, and Andreas Kruck. 2012. International Organization, 2nd ed Houndmills, New York: Palgrave Macmillan.

Rosand, Eric. 2004. "The Security Council as "Global Legislator": Ultra Vires or Ultra Innovative?" Fordham International Law Journal 28:542-90.

Salomon, Margot E. 2015. "Of Austerity, Human Rights and International Institutions." European Law Journal 21(4):521-45.

Scharpf, Fritz W.. 1988. "The Joint-Decision Trap: Lessons from German Federalism and European Integration." Public Administration 66:237-78.

Schelkle, Waltraud. 2014. "Fiscal Integration by Default." In Beyond the Regulatory Polity? The European Integration of Core State Powers, edited by Philipp Genschel, and Markus Jachtenfuchs, 105-23. Oxford: Oxford University Press. 
Scheppele, Kim L.. 2006. "The Migration of Anti-Constitutional Ideas: The Post-9/11 Globalization of Public Law and the International State of Emergency." In The Migration of Constitutional Ideas, edited by Sujit Choudhry, 347-73. Cambridge: Cambridge University Press.

Scheppele, Kim L. 2010. "Exceptions That Prove the Rule: Embedding Emergency Government in Everyday Constitutional Life." In The Limits of Constitutional Democracy, edited by Jeffrey Tulis, and Stephen Macedo, 124-54, University Center for Human Values series. Princeton: Princeton University Press.

Scheppele, Kim L. 2012. "The New Judicial Deference." Boston University Law Review 92(1):89-170.

Scheuerman, William E. 2006. "Survey Article: Emergency Powers and the Rule of Law After 9/11." Journal of Political Philosophy 14(1):61-84.

Scheuerman, William E. 2017. "Executive and Exception." In Handbook of Global Constitutionalism, edited by Anthony F. Lang, and Antje Wiener. Cheltenham, UK: Edward Elgar.

Scheuerman, William E. 2018. "States of Emergency Beyond the Nation State?" In Vienna Lectures on Legal Philosophy: Volume I: Legal Positivism, Institutionalism and Globalisation, edited by Christoph Bezemek, Michael Potacs, and Alexander Somek, 65-79. Portland, Oregon: Hart Publishing.

Schimmelfennig, Frank. 2015. "Liberal Intergovernmentalism and the Euro Area Crisis." Journal of European Public Policy 22(2):177-95.

Schmitt, Carl. 2014 [1928]. Dictatorship: From the Origin of the Modern Concept of Sovereignty to Proletarian Class Struggle. Cambridge: Polity. Translated by Michael Hoelzl and Graham Ward.

Schott, Jared. 2007. "Chapter VII as Exception: Security Council Action and the Regulative Ideal of Emergency." Northwestern University Journal of International Human Rights 6:24-80.

Sorell, Tom. 2013. Emergencies and Politics: A Sober Hobbesian Approach. Cambridge: Cambridge University Press.

Stone, Randall W. 2011. Controlling Institutions: International Organizations and the Global Economy. Cambridge: Cambridge University Press.

Szasz, Paul C. 2002. "The Security Council Starts Legislating." American Journal of International Law 96:901-4.

Tarrow, Sidney G. 2015. War, States, and Contention. Ithaca: Cornell University Press.

Trichet, Jean-Claude. 2010. "Speech by Jean-Claude Trichet, President of the ECB, at the 38th Economic Conference of the Oesterreichische Nationalbank," May 31. Accessed December 12, 2018 https://www. ecb.europa.eu/press/key/date/2010/html/sp100531_2.en.html.

Tuori, Kaarlo, and Klaus Tuori. 2014. The Eurozone Crisis: A Constitutional Analysis. Cambridge studies in European law and policy. Cambridge: Cambridge University Press.

United Nations Security Council (UNSC). 2004. "Verbatim records of the open Council meetings on the resolution draft.” S/PV/.4950 (22 April 2004). Accessed December 12, 2018. https://undocs.org/en/S/ PV.4950.

Vinx, Lars. 2013. "Carl Schmitt and the Analogy Between Constitutional and International Law: Are Constitutional and International Law Inherently Political?" Global Constitutionalism 2(1):91-124.

Viola, Lora, Duncan Snidal, and Michael Zürn. 2015. "Sovereign (in)Equality in the Evolution of the International System." In The Oxford Handbook on Transformation of the State, edited by Stephan Leibfried, Evelyne Huber, Matthew Lange, Jonah D. Levy, Frank Nullmeier, and John D. Stephens, 221-36. Oxford: Oxford University Press.

Waever, Ole. 1995. "Securitization and Desecuritization." In On Security, edited by Ronnie D. Lipschutz, 46-86. New York: Columbia University Press.

Washington Post. 2003. "The SARS Triumph and What It Promises." Washington Post, July 20.

Weaver, Catherine. 2008. Hypocrisy Trap: The World Bank and the Poverty of Reform. Princeton: Princeton University Press.

White, Jonathan. 2015a. “Authority After Emergency Rule.” Modern Law Review 78(4):585-610.

White, Jonathan. 2015b. "Emergency Europe." Political Studies 63(2):300-318.

WHO. 2003. "World Health Organization Issues Emergency Travel Advisory." March 15, 2003. Accessed December 12, 2018 http://www.who.int/mediacentre/news/releases/2003/pr23/en/.

WHO. 2004. "Summary of probable SARS cases with onset of illness from 1 November 2002 to 31 July 2003." April 21, 2004. Accessed December 12, 2018. http://www.who.int/csr/sars/country/ table2004_04_21/en/. 
Zacher, Mark W., and Tania J. Keefe. 2008. The Politics of Global Health Governance: United by Contagion. New York, Basingstoke: Palgrave Macmillan.

Zangl, Bernhard. 2006. Die Internationalisierung der Rechtsstaatlichkeit: Streitbeilegung in GATT und WTO. Frankfurt am Main: Campus.

Zürn, Michael. 2018. A Theory of Global Governance: Authority, Legitimacy, and Contestation. Oxford: Oxford University Press.

Zürn, Michael, Martin Binder, and Matthias Ecker-Ehrhardt. 2012. "International Authority and Its Politicization.” International Theory 4(1):69-106.

Cite this article: Kreuder-Sonnen, C. 2019. International authority and the emergency problematique. IO empowerment through crises. International Theory 11: 182-210, doi:10.1017/S1752971919000010 